$\mathrm{Oz}$

Volume 3

Article 15

$1-1-1981$

\title{
A House for Three Generations and a Private Museum: Kansas City, Missouri
}

Therese G. Cermak

Follow this and additional works at: https://newprairiepress.org/oz

(c) $(i) \Theta(9$

This work is licensed under a Creative Commons Attribution-Noncommercial-No Derivative Works 4.0 License.

\section{Recommended Citation}

Cermak, Therese G. (1981) "A House for Three Generations and a Private Museum: Kansas City, Missouri," Oz: Vol. 3. https://doi.org/10.4148/2378-5853.1030

This Article is brought to you for free and open access by New Prairie Press. It has been accepted for inclusion in Oz by an authorized administrator of New Prairie Press. For more information, please contact cads@k-state.edu. 


\title{
A House for Three Generations and a Private Museum
}

\author{
Kansas City, Missouri \\ Therese G. Cermak
}

The difficulty in writing about my Design Six thesis is trying to remember what in the hell was going on. O course, I remember the pressure to meet deadlines and fulfill requirements. I did graduate. But the intriguing aspect of my project is that it happened during a time when I was overwhelmed with new ideas. I was just starting to learn so much, or starting to see how much I had not yet learned, that a mist of confusion clouded my work on the thesis. It would have been a wonderful opportunity to really work over some ideas, but my mind was numb and I felt so intellectually clumsy. The result was that I dealt with that project in the way I had been taught. It was no masterpiece but quite acceptable in normal terms. You can see it in the drawing. But the drawing speaks to me privately There is a vacancy in it that reminds me it wasn't quite right. The most important thing was missing. That is what I want to talk about; not about the program being a house and museum for a family of three generations in Kansas City or about the social implications of extended family living in today's society or about appropriate responses to existing context or about concern for alternative energy technologies. These are all debatable, even irrelevant topics. I want to talk about what was real for me; the change in attitude that finally taught me something about myself.

It had no beginning. I always felt that there had to be more to archi-

tecture than problem solving. But I suppose school is a way you can start learning this by going through several years of practice before confronting the real thing, like repeatedly circling a victim before the attack. By Design Three I had my first identity-of-architecture crisis. I had just finished a project that was painfully, obviously, lacking something. To everyone else the project seemed successful. In their eyes I had solved the problem and there was nothing objectionable about the way the thing looked. But I knew that couldn't be right. It was objectionable to me precisely because I had just solved problems. I was learning technology. The big distinction arose here. To some people architecture meant producing acceptable buildings. I expected much more from it. Not because I thought there was a right way and a wrong way, but because I wanted it to mean more to me than work. I wanted to gain some satisfaction from this. I didn't want it to come to me so easily as if all I needed was a checklist and when the list was completed I had made architecture.

Through Design Five, I had still not resolved a thing. I was reaching, but for what? How can you grab onto such ambiguity? Slowly, happily, finally, things began to change. I started to read strange books about semiotics and philosophy which introduced me to the suggestion that there is no reality and that we have built up our own interpretation of the world through language. A word is not the same as the object or concept it represents, it is one step removed from its realness. All of our thinking and communicating is done through this system of language which carries us farther and farther away from the essence of things. I was confused about all this, but I was excited too. Something clicked in my mind, something in all this confusion rang true. Then a minor trauma came along named Peter Eisenman.

When I found out Eisenman was coming to school and would conduct a studio, I read up on his earlier work to get some kind of background. Eisenman was working with structure the same way that language involves a structure. The thing that was so striking, that I recall most clearly, was that he dealt with architecture as an independent system. His houses were conscious of their singular existence, they did not exist as empty shells waiting for fulfillment from other sources. There were no allusions, no metaphors, no cliches. Each house was derived from its own set of rules which kept arbitrary decisions to an absolute minimum, the same way languages operate. So with this naive understanding and much curiosity I began working with the man on his studio project.

Without getting into the complicated details of the process, I was given a series of rules and asked to make architecture from them. The things I remember that were so important to me were that I was dealing with mathematical rules, he never explained the source of those rules, the reason for his choice of them, and there were no rules for judging the final product. I had only begun to realize that much when the studio was over and Eisenman was gone. For weeks afterward I kept going over in my mind what I had done and came to several conclusions. It doesn't matter how you begin the process of design, but that once you begin you have to have reasons for what you do with the design and that it is impossible for more than one person to agree on what is architecture and what is not This all pointed to the conclusion that everything depended on the individual. It was all right to begin where you intuitively had the urge to begin. It was all right to say that you just knew when you saw architecture, you could feel it when it was there and when it was not there. In a way it was extremely reassuring for me to know that I could not have complete control and I would never know anything for sure. So I quit trying to look for answers and instead continued to ask questions.

During Design Six I took two other classes which helped me develop my ideas further. One was called, too simply, Semiotics and the other was 20th Century Art History. In Semiotics my understanding of language was sharpened to a further, deeper level. Beyond the obvious response to language as words, sentences and communication, I came to see how we are irreversibly affected by it. Language is the transition from chaos to order, it's the way we think, 
it guides and even initiates our ideas. It gives mankind the potential to develop in a direction. It leads us to think that we need bigger, better, faster ways of doing everything. It gives us the idiotic desire to consume everything around us as if we are trying to run away from something, as if we need to understand and control everything. Art History reminded me that there is one thing we cannot, or should not, consume - the soul, humanness, the chaos that still exists within us. The source of a creative work is a spark from that chaos, and our response to a creative work comes from that same elusive source. Art can never come easily because it is a struggle with ambiguity. Art is a reminder that in spite of our vast technological achievements we are human. Art is the difference between building and architecture. To bring art into a design you have to work with things you do not understand, i.e., feelings, emotions, responses, reinforcing the idea that seeing the quality of architecture is a relative thing our emotions are so elusive. It took considerable self-control to accept that as a final word, but those were the things I wanted my work in architecture to keep in touch with.

Where did all this leave my Design Six project? Out in the cold somewhere. As I said before, by that point I was too numb and confused to put my ideas to immediate use. Except for one trivial thing. By the end of the semester, when it was too late to save the design, I was finally able to see something surprisingly meaningful turn up in my drawing for the project, the one included here. It was a source of confrontation between myself and almost everyone else. To me it was the only way I could have presented the thing. But to others it did not conform to generally accepted methods of presentation. The point was that any drawing would have been only a representation of the conceptual project. How could one representation be more real than another? The drawing I chose to do showed more about my feelings for the project

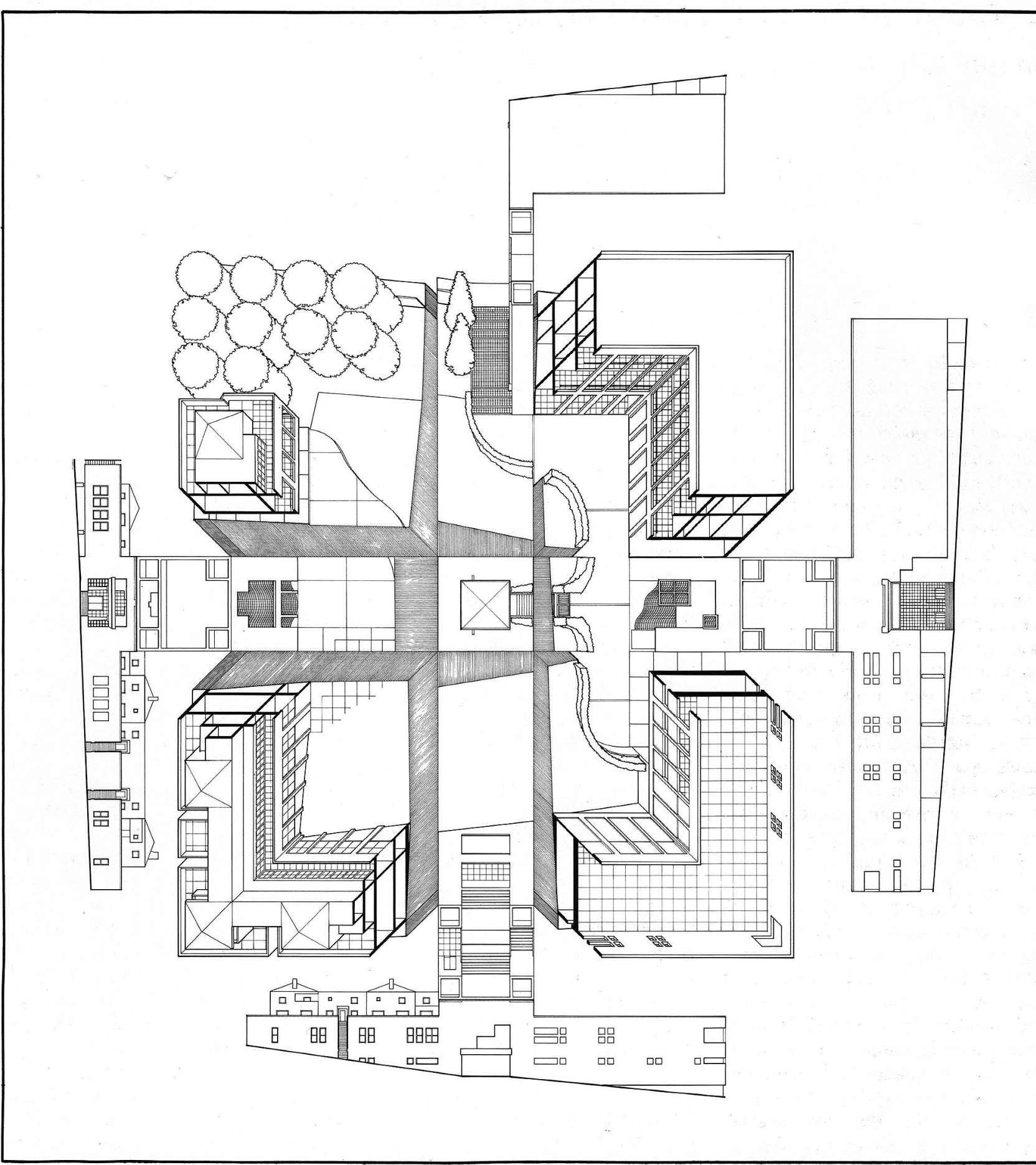

than any separate drawings would have. I was just starting to see what was really relevant for me to learn and there was no right or wrong about it. I had adopted some ideas that changed my perception of the whole project, of the whole world. The important thing that was missing was not so far away.
That is the significance I retain from my thesis project. I find the most value in knowing what it does not have. Yes, I am still confused and unsure of what I have said here and what I continue to think about now. It's painful sometimes, but. I would be missing so much if I didn't care to go on.
Composite axonometric showing site, sections, interior and exterior elevations 